\title{
Effect of Cortisol on Gene Expression of the Renin-Angiotensin System in Fetal Sheep
}

\author{
JEFFREY L. SEGAR, KURT BEDELL, WILLIAM V. PAGE, JON E. MAZURSKY, \\ ANNE-MONIQUE NUYT, AND JEAN E. ROBILLARD \\ Department of Pediatrics and the Cardiovascular Center, University of Iowa, \\ Iowa City, Iowa 52242
}

\section{ABSTRACT}

\begin{abstract}
Components of the renin-angiotensin system have been found in a variety of tissues during fetal and postnatal life and appear to be developmentally regulated. We postulated that hormonal changes associated with parturition participate in the regulation of renin, angiotensinogen (Ao) and angiotensin type 1 receptor $\left(\mathrm{AT}_{1}\right)$ gene expression. Cortisol, which increases rapidly in fetal blood before delivery, has been shown to influence the maturation of various systems in the developing fetus. To test the hypothesis that an increase in cortisol regulates fetal renin, Ao, and $\mathrm{AT}_{1}$ mRNA gene expression, we used Northern blot analysis to study the effects of an intraperitoneal infusion of cortisol $(3 \mathrm{mg} / \mathrm{h}, 1 \mathrm{~mL} / \mathrm{h})$ for $48 \mathrm{~h}$ on the expression of these genes in twin ovine fetuses ( $n=10$ pairs) at 130-d gestation (term $145 \mathrm{~d}$ ); one twin in each pair served as a saline-treated control $(0.9 \%$ $\mathrm{NaCl}, 1 \mathrm{~mL} / \mathrm{h}$ ). Plasma cortisol levels were significantly higher in cortisol-treated fetuses $(113 \pm 23 \mathrm{nmol} / \mathrm{dL})$ than in twin controls $(4.6 \pm 0.8 \mathrm{nmol} / \mathrm{dL})$. Cortisol infusion significantly decreased $\mathrm{AT}_{1}$ receptor mRNA levels in kidney and liver by $24 \pm 7 \%$ and $27 \pm 8 \%$, respectively, when compared with
\end{abstract}

The RAS has been established to be an important regulator of hemodynamic and fluid and electrolyte homeostasis during fetal, newborn, and adult life. More recently, it has been suggested that the RAS exerts a major influence on cellular growth and organ differentiation (1-4). Although these effects may be mediated by circulating AII, there are reasons to believe that local RAS exist within individual organs or tissues (5) and may participate in these functions.

Studies in newborn infants (6) and newborn animals (7) have shown that the activity of the RAS increases at birth. In addition, developmental changes in the expression of several components of the RAS have recently been documented (810). Despite the importance of the RAS in maintaining phys-

Received October 17, 1994; accepted February 8, 1995.

Correspondence: Jeffrey L. Segar, M.D., Department of Pediatrics, University of Iowa Hospitals and Clinics, 200 Hawkins Drive, Iowa City, IA 52242.

Supported by National Institutes of Health Grants HL-14388, DK-38302, and DK43961 .

J.L.S. is supported by a Clinical Investigator Development Award (HL-02865). controls $(p<0.05)$, whereas in contrast, increased mRNA levels $(p<0.05)$ in heart right atrium $(91 \pm 23 \%)$ and ventricle $(59 \pm$ $20 \%$ ). Renin mRNA levels decreased in renal cortex by $77 \pm$ $13 \%(p<0.05)$ in cortisol-treated animals compared with controls. Hepatic Ao mRNA levels decreased by $15 \pm 5 \%$ in response to cortisol $(p<0.05)$, whereas no significant effect was seen on renal Ao gene expression. These findings demonstrate that cortisol exhibits tissue specific positive and negative regulation of renin, $\mathrm{Ao}$ and $\mathrm{AT}_{1}$ receptor gene expression during fetal life and may act as an important modulator of the reninangiotensin system during parturition. (Pediatr Res 37: 741-746, 1995)
AII, angiotensin II
Abbreviations
Ao, angiotensinogen
AT 1 , angiotensin II type 1 receptor
PRA, plasma renin activity
RAS, renin-angiotensin system

iologic homeostasis, few studies have investigated the factors regulating developmental changes in the expression of these genes. We have previously demonstrated that renal innervation is vital to the increase in kidney renin mRNA expression at birth (11), but has no effect on renal $\mathrm{AT}_{1}$ receptor gene expression in 24-h-old newborn lambs (12). Studies in rats have demonstrated that maternal dexamethasone administration enhances expression of the Ao gene during fetal life (8); however, fetal sheep liver Ao and renal $\mathrm{AT}_{1}$ gene expression are negatively regulated by glucocorticoids $(12,13)$.

The present study was designed to investigate whether cortisol, which is known to increase rapidly in fetal blood before delivery (14) and influence the maturation of various systems in the developing fetus (15), regulates gene expression of several components of the RAS in fetal ovine tissues. Arterial hemodynamic and hormonal values from the animals in this study, and the effect of cortisol on renal $\mathrm{AT}_{1}$ receptor mRNA levels have recently been published elsewhere (12) and thus only directly pertinent values are included in this text. 


\section{METHODS}

Animal preparation and surgical procedures. Studies were performed in 10 pairs of twin fetal sheep at 130 -d gestation, term being $145 \mathrm{~d}$. Pregnant ewes of Dorset and Suffolk mixed breeding were obtained from a local source; gestational ages were based on the induced ovulation technique as previously described (16).

Surgical preparation. Anesthesia and surgery of the ewe and fetus were performed as previously described $(11,13)$. Briefly, the ewe was fasted for $24 \mathrm{~h}$ before surgery and anesthetized using a mixture of halothane $(1 \%)$, oxygen $(33 \%)$, and nitrous oxide $(66 \%)$. Under sterile conditions, the uterus was opened over the fetal hindlimbs and polyethylene catheters were placed into the fetal femoral arteries and veins bilaterally. A catheter for recording amniotic pressure was secured to the fetal skin. Additional catheters were placed in the peritoneal cavity of each twin.

At the end of surgery, the fetal skin incisions were closed and the fetus was returned to the uterus. Maternal incisions were closed in separate layers. All catheters were exteriorized through a s.c. tunnel and placed in a cloth pouch on the ewe's flank. Ampicillin sodium (Wyeth Laboratories, Philadelphia, PA) was administered to the ewe intramuscularly before surgery $(2 \mathrm{~g})$ and infused into the amniotic cavity after surgery $(2 \mathrm{~g})$. Pregnant ewes were returned to individual pens and allowed free access to food and water. The animals were allowed $3 \mathrm{~d}$ to recover from surgery before beginning the experiments. All procedures were performed within the regulations of the Animal Welfare Act and the National Institutes of Health Guide for the Care and Use of Laboratory Animals, and were approved by the University of Iowa Animal Care and Use Committee.

Experimental protocol. After a 3-d recovery period from surgery, one of each set of twins was administered a continuous intraperitoneal infusion of cortisol for exactly $48 \mathrm{~h}$ at a rate of $3 \mathrm{mg} / \mathrm{h}(1 \mathrm{~mL} / \mathrm{h})$. The other twin served as a paired control and received an intraperitoneal infusion of $0.9 \% \mathrm{NaCl}$ at a similar rate $(1 \mathrm{~mL} / \mathrm{kg})$. The infusions were carried out with portable constant infusion pumps (Cormed, Inc., Middleport, NY) secured on the back of the ewe in pockets of a specially designed jacket that allowed the animals to move freely during the infusion.

Arterial blood pressure, heart rate, and amniotic pressure were monitored in each fetus for $30 \mathrm{~min}$ immediately before and at the end of the $48 \mathrm{~h}$ intraperitoneal infusion. Arterial blood from each fetus was taken before and $48 \mathrm{~h}$ after starting the cortisol infusion for determination of arterial $\mathrm{pH}, \mathrm{PCO}_{2}, \mathrm{PO}_{2}$, plasma cortisol and AII concentrations, and PRA. This duration of infusion was chosen as in vitro studies investigating the effects of glucocorticoids on the vascular smooth muscle $\mathrm{AT}_{1}$ receptor showed a maximal increase in $\mathrm{AT}_{1}$ receptors at $48 \mathrm{~h}$ (17). At the end of the infusion period, ewes were anesthetized as described above, the uterine cavity was opened, and sections of heart (all four chambers), peripheral lung, liver, adrenal, and renal cortex were removed, snap frozen in liquid nitrogen, and stored at $-70^{\circ} \mathrm{C}$.
Isolation of RNA and preparation of probes. Total cellular RNA was extracted using a modified isothyiocyanate- $\mathrm{CsCl}$ method as previously described (9). RNA concentrations were determined spectrophotometrically by absorbance at $260 \mathrm{~nm}$. RNA samples were stored as an ethanol precipitate at $-70^{\circ} \mathrm{C}$ until further analysis.

All experiments were performed with RNA probes complimentary to the sequences of interest. A clone containing fulllength rat Ao cDNA (pRANG6) (18) was obtained from Dr. K. R. Lynch (University of Virginia, Charlottesville, VA). This cDNA yields the antisense RNA when transcribed from the T7 promoter after linearization with EcoRI. A clone containing a $0.7-\mathrm{kb}$ fragment of rat renin cDNA was prepared from a full-length 1.43 -kb rat renin cDNA (19) also obtained from K. R. Lynch. After linearization with EcoRI, transcription from the $\mathrm{T} 7$ promoter yields the antisense RNA.

The sheep $\mathrm{AT}_{1}$ partial cDNA was prepared as previously described by our group (12) and recloned into the SpeI and KpnI restriction sites of pBluescript II SK- (Stratagene) yielding the subclone $\mathrm{pAT}_{1}$. The plasmid $\mathrm{pAT}_{1}$ was treated with the restriction enzyme $N d e I$ and then purified by phenol:chloroform:isoamyl alcohol $(25: 24: 1)$ and ethanol precipitation. The resultant linear plasmid was used to generate an antisense RNA probe using T7 RNA polymerase (U.S. Biochemical Corp., Cleveland, $\mathrm{OH})$. Radiolabeled probes were generated using $\mathrm{D}-\left[{ }^{32} \mathrm{P}\right] \mathrm{UTP}$.

An 18S rRNA probe was used to confirm equal loading and transfer of RNA. The 18S rRNA was prepared from $18 \mathrm{~S}$ cDNA clone corresponding to a 82-bp fragment of a highly conserved region of human 18S ribosomal RNA (Ambion Inc., Austin, TX).

Northern blot hybridization. Aliquots of 5-10 $\mu \mathrm{g}$ of RNA as measured by absorbance at $260 \mathrm{~nm}$ were fractioned by formaldehyde-argose gel electrophoresis (20). After electrophoresis, RNA was transferred to $0.45-\mathrm{mm}$ Nytran filters. The filters were prehybridized for $1 \mathrm{~h}$ at $60^{\circ} \mathrm{C}$ in a solution of $50 \%$ deionized formamide, $5 \times$ SSPE, $5 \times$ Denhardt's reagent, $0.5 \% \mathrm{SDS}$, and $200 \mu \mathrm{g} / \mathrm{mL}$ denatured sheared salmon sperm DNA. Hybridization of filters was carried out with fresh hybridization buffer solution containing $2 \times 10^{6}$ counts $/ \mathrm{min} / \mathrm{mL}$ of the appropriate radiolabeled probe. The hybridization reaction was carried out at $60^{\circ} \mathrm{C}$ for $12-18 \mathrm{~h}$.

Filters were washed according to the manufacturer's specifications. This included three low stringency washes $(1 \times$ SSPE, $0.5 \%$ SDS $)$ at $68^{\circ} \mathrm{C}$ and a high stringency wash $(0.1 \times$ SSPE, $0.5 \%$ SDS) at $65^{\circ} \mathrm{C}$. Hybridization signals were detected and quantitated using an AMBIS 4000 Radioanalytic Imaging System (AMBIS Inc., San Diego CA). The AMBIS 4000 simultaneously images and quantitates the radioisotopic signal generated by ${ }^{32} \mathrm{P}$ on the filters as previously described (12). Background counts above each lane were determined and subtracted from the total counts generated in each region of interest to yield a net count value. The washed filters were additionally exposed to Kodak XAR film at $-70^{\circ} \mathrm{C}$.

The filters used for the determination of $\mathrm{AT}_{1}$ mRNA were also used to probe for renin mRNA and Ao mRNA. Before rehybridizing with a second RNA probe, the first RNA probe was stripped from the filters by washing in a solution of $50 \%$ 
formamide and $6 \times \mathrm{SSPE}$ at $70^{\circ} \mathrm{C}$ for $30 \mathrm{~min}$ and by rinsing in $2 \times$ SSPE at $24^{\circ} \mathrm{C}$.

Analytical procedures. Arterial blood for $\mathrm{pH}, \mathrm{PCO}_{2}$ and $\mathrm{Po}_{2}$ was collected anaerobically in heparinized syringes, and measurements immediately determined using an IL-1303 pH blood gas analyzer (Laboratory Instruments, Schaumburg IL) at $39.5^{\circ} \mathrm{C}$. Measurements of plasma cortisol (13) and AII concentrations (interassay and intraasssay variabilities of 12.7 and $5.5 \%$, respectively) (21) and PRA (interassay and intraassay variabilities of 12.1 and $7.9 \%$, respectively) $(21,22)$ were performed by radioimmunoassay as previously established in our laboratory.

Data analysis. For quantitation of mRNA abundance, all individual tissue samples were analyzed together on a single Northern blot hybridization to control for day-to-day variations in hybridization efficiency. Northern blots were done in triplicate. Abundances of $\mathrm{AT}_{1}$, renin and Ao mRNA were expressed as total net radioactive counts after subtracting background counts for each sample.

Comparisons of arterial blood and hemodynamic values among groups were performed using one-way analysis of variance. If the $F$ statistic was found to be significant, comparisons among means was performed by the Duncan multiple comparison procedure (23). Comparisons of mRNA abundance between groups were performed by paired $t$ tests. Statistical significance is defined as $p<0.05$, and results are presented as mean \pm SEM.

\section{RESULTS}

The effects of cortisol infusion on systemic hemodynamics and arterial blood values have previously been published (12). Fetal plasma cortisol concentrations were similar in both groups before cortisol infusion $(2.3 \pm 0.4$ versus $3.2 \pm 0.7$ $\mathrm{nmol} / \mathrm{dL}$ for control and treated groups, respectively). Cortisoltreated fetuses had significantly higher $(p<0.001)$ plasma cortisol values at $48 \mathrm{~h}(112.6 \pm 23.1 \mathrm{nmol} / \mathrm{dL})$ compared with control fetuses $(4.6 \pm 0.8 \mathrm{nmol} / \mathrm{dL})$. PRA decreased significantly from $5.47 \pm 1.26$ to $1.21 \pm 0.32 \mathrm{ng} \mathrm{AI} / \mathrm{mL} / \mathrm{h}$ in cortisol treated fetuses, whereas no changes were detected in plasma AII levels in either group. Mean arterial blood pressure was similar between groups.

Effects of cortisol infusion on $A T_{1}$, renin and Ao $m R N A$ levels. We postulated that cortisol, which increases rapidly in fetal blood before birth (14), and is known to influence the maturation of various systems in the developing animal (15), regulates the increased activity of the RAS seen at birth $(7,11)$. The effects of cortisol administration on $\mathrm{AT}_{1}$ mRNA levels are shown in Table 1 and Figure 1. Northern blot hybridization demonstrated significant decreases in renal and hepatic $\mathrm{AT}_{1}$ mRNA levels in cortisol-treated fetuses of $24 \pm 7 \%$ and $27 \pm$ $8 \%$, respectively, compared with controls. In contrast, cardiac $\mathrm{AT}_{1}$ mRNA levels increased in response to cortisol infusion. Right atrium $\mathrm{AT}_{1}$ mRNA increased $91 \pm 23 \%$ when compared with saline-treated controls, whereas right ventricle and left atrium $\mathrm{AT}_{1}$ mRNA increased by $59 \pm 20 \%$ and $37 \pm 12 \%$, respectively. No significant changes in $\mathrm{AT}_{1} \mathrm{mRNA}$ levels were seen in the left ventricle or adrenal tissues.

The response of fetal renin mRNA levels to plasma cortisol infusion are shown in Table 1 and Figure 2. The Northern blot analysis demonstrates that cortisol administration resulted in decreased kidney renin mRNA levels. Total net ${ }^{32} \mathrm{P}$ radioactive counts demonstrated that cortisol administration resulted in a $77 \pm 13 \%$ decrease in kidney renin mRNA $(p<0.05)$ and a $31 \pm 20 \%$ increase in adrenal $(p=0.055)$ renin mRNA. As shown by Northern blot analysis, cortisol administration also decreased hepatic Ao mRNA levels by $15 \pm 5 \%$ compared with controls, whereas no significant effect was seen on kidney Ao mRNA abundance. Hybridization to an $18 \mathrm{~S}$ rRNA probe showed no significant differences between control and cortisoltreated fetuses for any tissue type (Table 2), indicating similar RNA loading.

Levels of renin mRNA by Northern blot analyses were too low for accurate quantitation in lung, heart, and liver, and for Ao mRNA in lung, heart, or adrenal tissue.

\section{DISCUSSION}

Recent findings suggest that early during development, the RAS not only regulates cardiovascular, fluid, and electrolyte homeostasis $(7,24)$, but also influences cellular growth and local tissue function $(25,26)$. Components of the RAS have been found in many extrarenal tissues $(5,27)$, supporting the notion of independent tissue RAS and locally generated angiotensins regulating cellular differentiation and function. In the present study, we hypothesized that cortisol, which increases rapidly before delivery and further with birth $(14,28)$ and has previously been shown to influence the maturation of various

Table 1. Abundance of $A T_{1}$, renin, and angiotensinogen $m R N A$, expressed as total net counts of ${ }^{32} P$, in various fetal sheep tissues

\begin{tabular}{|c|c|c|c|c|c|c|c|c|}
\hline mRNA & Kidney & Lung & Adrenal & Liver & $\begin{array}{c}\text { Left } \\
\text { ventricle }\end{array}$ & $\begin{array}{c}\text { Right } \\
\text { ventricle }\end{array}$ & $\begin{array}{c}\text { Left } \\
\text { atrium }\end{array}$ & $\begin{array}{l}\text { Right } \\
\text { atrium }\end{array}$ \\
\hline \multicolumn{9}{|l|}{$\mathrm{AT}_{1}$} \\
\hline Control & $1244 \pm 103$ & $2332 \pm 375$ & $9685 \pm 918$ & $9963 \pm 481$ & $579 \pm 86$ & $396 \pm 56$ & $317 \pm 47$ & $260 \pm 60$ \\
\hline Cortisol & $928 \pm 74 *$ & $1591 \pm 199$ & $13207 \pm 1384 \dagger$ & $3630 \pm 253^{*}$ & $735 \pm 76$ & $628 \pm 77^{*}$ & $435 \pm 63^{*}$ & $496 \pm 76^{\circ}$ \\
\hline \multicolumn{9}{|l|}{ Renin } \\
\hline Control & $1194 \pm 277$ & & $2174 \pm 199$ & & & & & \\
\hline Cortisol & $280 \pm 80^{*}$ & & $2840 \pm 255 \dagger$ & & & & & \\
\hline \multicolumn{9}{|c|}{ Angiotensinogen } \\
\hline Control & $158 \pm 16$ & & & $9409 \pm 595$ & & & & \\
\hline Cortisol & $189 \pm 17$ & & & $7980 \pm 429 *$ & & & & \\
\hline
\end{tabular}

Values are means $\pm \mathrm{SE}$.

$* p<0.05$ compared to control value.

$\dagger p=0.06$ compared to control value. Cortisol, $48 \mathrm{~h}$ after starting intraperitoneal infusion of cortisol $(3 \mathrm{mg} / \mathrm{h})$. 


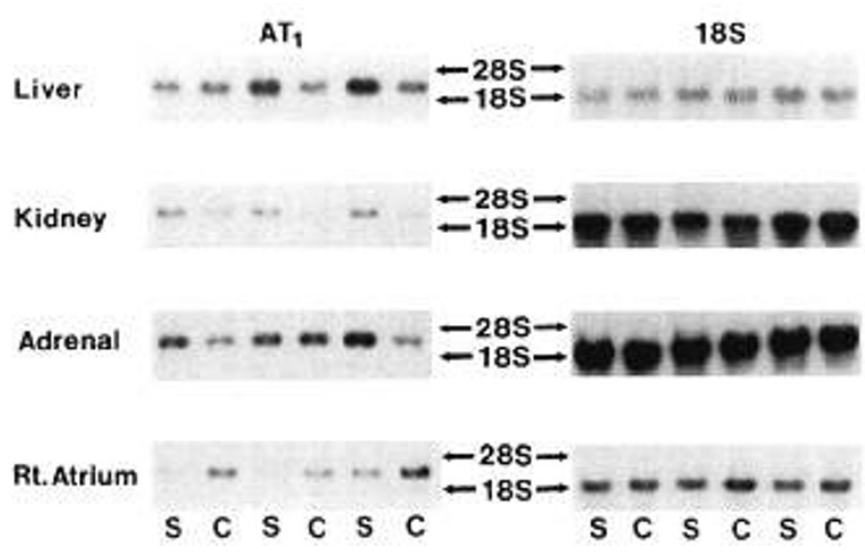

Figure 1. Representative autoradiograms of Northern blots of liver, kidney, adrenal, and right atrium RNA hybridized with a sheep AT1 RNA probe (left) and with a human $18 \mathrm{~S}$ rRNA probe (right) labeled with ${ }^{32} \mathrm{P}$. Tissue RNA was extracted from saline-infused $(0.9 \% \mathrm{NaCl})(S)$ and cortisol-infused $(C)$ twin fetal sheep at 130-d gestation. Each pair of saline-infused and cortisol-infused blots represents twin fetuses studied simultaneously.
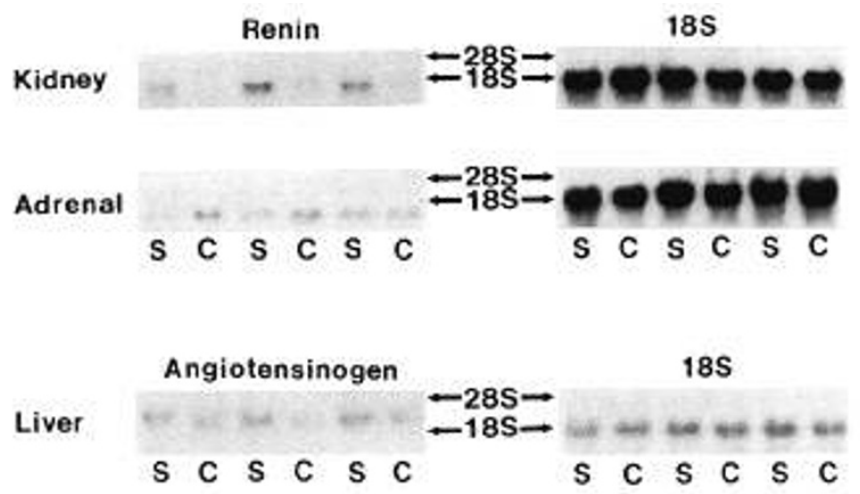

Figure 2. Upper panel, Representative autoradiograms of Northern blots of total renal cortical RNA and adrenal RNA hybridized with rat renin RNA probe (left) and with a human $18 \mathrm{~S}$ rRNA probe (right) labeled with ${ }^{32} \mathrm{P}$. Tissue RNA was extracted from saline-infused $(0.9 \% \mathrm{NaCl})(S)$ and cortisol-infused $(C)$ twin fetal sheep at 130-d gestation. Each pair of saline-infused $(S)$ and cortisol-infused $(C)$ blots represents twin fetuses studied simultaneously. Lower panel, Autoradiogram of a Northern blot of liver RNA hybridized with a rat Ao RNA probe (left) and with a human 18S rRNA probe (right) labeled with ${ }^{32} \mathrm{P}$.

organ systems late during fetal life (15), regulates the expression of several genes involved in the RAS. Studies in fetal sheep (14) have shown that cortisol levels increase rapidly beginning $5 \mathrm{~d}$ before parturition $(15-30 \mathrm{nmol} / \mathrm{dL})$, and in the last $12-24 \mathrm{~h}$ of fetal life, a pronounced increment occurs, with levels exceeding $60 \mathrm{nmol} / \mathrm{dL}$ at birth in animals delivered per vagina. Cortisol levels promptly fall within $1 \mathrm{~d}$ after birth but remain above basal fetal values (28). Our data provide evidence that cortisol mediates tissue-specific positive and negative regulation of several components of the RAS. More specifically, a rise in fetal plasma cortisol concentration to levels similar to those observed at the time of parturition produced a decrease in renal and hepatic but an increase in cardiac $\mathrm{AT}_{1}$ mRNA levels. In addition, renal renin mRNA and hepatic Ao mRNA levels were attenuated.

The $\mathrm{AT}_{1}$ receptor is abundantly expressed late during fetal development (25) and in the rat is predominantly located in areas related to blood pressure regulation and fluid and electrolyte homeostasis (25). Not surprisingly, it is during this period of development that AII becomes an important modulator of blood pressure $(7,24)$. For example, studies have shown that inhibition of AII synthesis, using captopril, affects blood pressure and renal hemodynamic responses to hemorrhage in near-term fetal and newborn sheep but not earlier during fetal development $(7,29)$. In addition, antenatal blockade of the RAS significantly reduces resting blood pressure in near-term fetal sheep (7) and negates the normal rise in arterial pressure after birth (30).

In support of the hypothesis that cortisol regulates $\mathrm{AT}_{1}$ mRNA levels during fetal life, in vitro studies have shown that dexamethasone increases $\mathrm{AT}_{1}$ gene expression in adult rat cultured vascular smooth muscle cells (17), this effect being blocked by a glucocorticoid antagonist. Our observation that cortisol administration increased cardiac $\mathrm{AT}_{1}$ mRNA levels is consistent with these previous results. On the other hand, cortisol infusion decreased renal and hepatic $\mathrm{AT}_{1}$ mRNA levels. The kidney $\mathrm{AT}_{1}$ data were derived independently of that already published (12) (thus explaining the slight differences in values) and replicates, but does not duplicate these results. Other investigators have similarly found that corticosteroids down-regulate rat glomerular AII receptors (31) and $\mathrm{AT}_{1}$ receptors in pancreatic acinar cells (32). One may therefore conclude that $\mathrm{AT}_{1}$ gene expression is differentially regulated by cortisol in a tissue-specific manner. It should be noted, however, that changes in $\mathrm{AT}_{1}$ mRNA levels do not necessarily reflect alterations in the abundance of $\mathrm{AT}_{1}$ receptor protein. Recent studies in rats have shown that $\mathrm{AT}_{1}$ mRNA in renal cortex is present before $\mathrm{AT}_{1}$ receptor ligand binding (33). Further studies are required to determine the relationship between $\mathrm{AT}_{1}$ mRNA levels and receptor density in developing animals.

The effect of cortisol on the distribution of $\mathrm{AT}_{1}$ receptor mRNA within specific tissue types was not addressed in the present study. Given the effect of corticosteroids on enhancing maturation in other tissues (15), one may speculate that cortisol induced developmental changes in the distribution of $\mathrm{AT}_{1}$ mRNA. In the rat, the intrarenal distribution of $\mathrm{AT}_{1}$ mRNA changes with maturation (10), becoming absent in the nephrogenic cortex, and more discretely localized to glomeruli, arteries and vasa recta. $\mathrm{AT}_{1}$ gene expression in renal tubules, however, remains low throughout ontogeny (34). Hence, the observed decrease in renal cortical mRNA levels in the present study may represent down-regulation of $\mathrm{AT}_{1}$ mRNA at specific sites within the kidney.

Increased plasma cortisol concentrations also produced tissue specific differential regulation of renin mRNA, decreasing renin mRNA levels in the kidney, whereas mRNA levels in the adrenal remain unchanged. Tissue-specific regulation of several components of the RAS has previously been reported (5, 27). Dzau and colleagues (27) found in mice that sodium depletion increases renin mRNA levels in kidney, heart and adrenal but not in the testis or submandibular gland. Additional studies in rats have shown that bilateral nephrectomy and combined hormone therapy produce a greater than 2-fold increase in liver Ao mRNA levels but decrease mRNA levels in aorta, adrenal and lung (5). Mechanisms by which cortisol produces differential regulation of genes of the RAS were not 
Table 2. Abundance of $18 S$ ribosomal mRNA expressed as total net counts of ${ }^{32} P$ in tissues examined

\begin{tabular}{|c|c|c|c|c|c|c|c|c|}
\hline & Kidney & Lung & Adrenal & Liver & Left ventricle & Right ventricle & Left atrium & Right atrium \\
\hline Control & $395 \pm 20$ & $40098 \pm 4206$ & $31208 \pm 5892$ & $22064 \pm 1043$ & $22813 \pm 942$ & $8504 \pm 738$ & $16085 \pm 540$ & $5982 \pm 140$ \\
\hline Cortisol-treated & $410 \pm 21$ & $43692 \pm 3546$ & $31702 \pm 5748$ & $21210 \pm 1158$ & $22457 \pm 1167$ & $8834 \pm 794$ & $16952 \pm 633$ & $6364 \pm 308$ \\
\hline
\end{tabular}

Values are means $\pm \mathrm{SE}$.

investigated, although several explanations can be suggested. Cortisol infusion may secondarily alter the local production of growth factors which act in a tissue specific manner to regulate gene transcription or stability (13). For example, it has recently been shown that the induction of specific growth factors account for the mitogenic effects of AII on vascular smooth muscle as these effects are blocked by the growth factor inhibitor suramin (3). Second, cellular-specific developmental changes in the physiochemical nature of glucocorticoid receptor, including receptor density and the presence of nonfunctional or modified receptors may alter the cellular sensitivity to glucocorticoids (35). In the $5^{\prime}$-flanking regions of the renin and Ao genes, glucocorticoid responsive elements have been identified that are thought to regulate gene expression (2). However, the positive or negative glucocorticoid regulation of gene expression likely depends on other factors interacting with the glucocorticoid regulatory elements. In mice, the presence of the oncogene c-jun confers a positive glucocorticoid effect to the glucocorticoid regulatory element, whereas the combination of c-jun and c-fos tends to confer a negative effect to the same element (36). Furthermore, it should be noted that cortisol exhibits both glucocorticoid and mineralocorticoid properties, the interaction of which may alter the regulation of certain genes. Indeed, the regulation of gene expression by mineralocorticoids may itself be tissue- and cell-specific as they have been shown to up-regulate AII receptors in neurons (37) while producing down-regulation of glomerular AII receptors (31). Clearly, additional studies are needed to clarify these issues.

The finding that an increase in plasma cortisol concentration decreased liver Ao mRNA levels in fetal sheep is in contrast to findings in mature animals (5) and fetal rats (8) in which glucocorticoids increase Ao mRNA accumulation. Reasons for these differences are not clear, but maybe due to the pharmacologic differences of cortisol versus dexamethasone or differences in species. There is clear evidence that species differences exist in terms of regulating expression of genes of the RAS. Hepatic Ao mRNA levels increase 3-fold from 60 to 138 $\mathrm{d}$ of gestation in fetal sheep, then decrease after birth (9). In contrast, liver Ao mRNA does not appear in the neonatal rat until about $24 \mathrm{~h}$ after birth (38). In addition, renal $\mathrm{AT}_{1}$ receptor mRNA levels increase after birth in rats (10) but not sheep (12). These ontogenic differences may be due to maturational differences between sheep and rat at the time of birth, inasmuch as the newborn lamb is more mature at birth than is the rat. Nonetheless, the present results are consistent with those of a previous study by our group (13) that demonstrated cortisol administration decreased liver Ao mRNA by $61 \%$ in $138 \mathrm{~d}$ fetuses but had no effect in 118-d fetuses. Interestingly, only a $15 \%$ decrease in Ao mRNA was seen in the present study which used fetuses of an intermediate age ( $130 \mathrm{~d})$ compared with those of the previous study. These results further support the hypothesis that regulation of Ao mRNA is developmentally regulated as previously suggested (13).

Recent work demonstrating local synthesis of components of the RAS in the heart supports the existence of a tissue-specific cardiac RAS (1). In the heart, renin, Ao, and angiotensinconverting enzyme gene expression has been demonstrated in several species (1), as has the existence of functional AII receptors $(1,34)$. Studies in rabbits and guinea pigs have found the angiotensin receptor density to be higher in atria than in ventricles (39), although other investigators have found $\mathrm{AT}_{1}$ receptors to be equally distributed (40). In the present study, $\mathrm{AT}_{1}$ mRNA levels were similar among left and right atria and ventricles. Other studies in rats have also reported essentially identical AII receptor mRNA quantities in left and right ventricle myocytes (41). Given the purported growth promoting effects of angiotensin $(1,41)$, it should not be surprising to find a uniform distribution of $\mathrm{AT}_{1}$ receptors within the developing fetal heart. Interestingly, Ao and renin mRNA are present in all four cardiac chambers in embryonic chick heart, but only in atria of 10-d-old chicks (42). Whether similar developmental changes in cardiac $\mathrm{AT}_{1}$ mRNA expression occurs in sheep has to our knowledge not been investigated.

Renin, $\mathrm{Ao}$, and $\mathrm{AT}_{1}$ gene expression have been shown by other investigators to be responsive to AII, although results are not consistent and appear tissue-dependent $(43,44)$. We observed no significant change in circulating AII levels in response to cortisol infusion, despite a decrease in PRA. Reasons for this phenomena have been discussed elsewhere (12). Nonetheless, one cannot ascribe the observed changes in $\mathrm{AT}_{1}$ mRNA levels, or the expression of other genes of the RAS examined in this study to changes in circulating AII levels.

In summary, our study demonstrates that cortisol differentially regulates gene expression of several components of the RAS in a tissue-specific manner early during development. These data also suggest that locally independent and biologically active RASs function at the cellular level. Further studies are needed to examine the developmental changes in localized RAS and how these systems are regulated.

Acknowledgment. The authors gratefully acknowledge the assistance of Mark A. Hart in the preparation of this manuscript.

\section{REFERENCES}

1. Lindpaintner K, Ganten D 1991 The cardiac renin-angiotensin system. An appraisal of present experimental and clinical evidence. Circ Res 68:905-921

2. Dzau VJ, Burt DW, Pratt RE 1988 Molecular biology of the renin-angiotensin system. Am J Physiol 255:F563-F573

3. Weber H, Taylor DS, Molloy CJ 1994 Angiotensin II induces delayed mitogenesis and cellular proliferation in rat aortic smooth muscle cells. J Clin Invest 93:788-798

4. Tufro-McReddie A, Johns DW, Geary KM, Dagli H, Everett AD, Chevalier RL, Carey RM, Gomez RA 1994 Angiotensin II type 1 receptor: role in renal growth and gene expression during normal development. Am J Physiol 266:F911-F918 
5. Campbell DJ, Habener JF 1986 Angiotensin gene is expressed and differentially regulated in multiple tissues of the rat. J Clin Invest 78:31-39

6. Tetlow HJ, Broughton-Pipkin F 1983 Studies on the effect of mode of delivery on the renin-angiotensin system in mother and fetus at term. Br J Obstet Gynaecol 90:220226

7. Robillard JE, Weismann DN, Gomez RA, Ayres NA, Lawton WJ, VanOrden DE 1983 Renal and adrenal responses to converting-enzyme inhibition in fetal and newborn life. Am J Physiol 244:R249--R256

8. Everett AD, Chevalier RL, Gomez RA 1991 Hepatic angiotensinogen gene regulation in the fetal and pregnant rat. Pediatr Res 30:252-255

9. Olson AL, Perlman S, Robillard JE 1990 Developmental regulation of angiotensinogen gene expression in sheep. Pediatr Res 28:183-185

10. Tufro-McReddie A, Harrison JK, Everett AD, Gomez RA 1993 Ontogeny of Type 1 angiotensin II receptor gene expression in the rat. J Clin Invest 91:530-537

11. Page WV, Perlman S, Smith FG, Segar JL, Robillard JE 1992 Renal nerves modulate kidney renin gene expression during the transition from fetal to newborn life. Am J Physiol 262:R459-R463

12. Robillard JE, Schutte BC, Page WV, Fedderson JA, Porter CC, Segar JL 1994 Ontogenic changes and regulation of renal angiotensin II type $1\left(\mathrm{AT}_{1}\right)$ receptor gene expression during fetal and newborn life. Pediatr Res 36:755-762

13. Olson AL, Robillard JE, Kisker CT, Smith BA, Perlman S 1991 Negative regulation of angiotensinogen gene expression by glucocorticoids in fetal sheep liver. Pediatr Res 30:256-260

14. Nathanielsz PW 1976 Adrenocorticotropin. In: Nathanielsz PW (ed) Fetal Endocrinology: An Experimental Approach, North-Holland Publishing, Amsterdam, pp $125-150$

15. Ballard PL 1979 Glucocorticoids and differentiation. Monogr Endocrinol 12:493-515

16. Jennings JJ, Crowley JP 1972 The influence of mating management on fertility in ewes following progesterone-PMS treatment. Vet Rec 90:495-498

17. Sato A, Suzuki H, Murakami M, Nakazato Y, Iwaita Y, Saruta T 1994 Glucocorticoid increases angiotensin II type 1 receptor and its gene expression. Hypertension 23:25-30

18. Lynch KR, Simnad V, Ben-Ari E, Garrison J 1991 Localization of preangiotensin messenger RNA sequences in the rat brain. Hypertension 540:543

19. Burnham CE, Hawelu-Johnson CL, Frank BM, Lynch KR 1987 Molecular cloning of rat renin cDNA and its gene. Proc Natl Acad Sci USA 84:5605-5609

20. Lehrach H, Diamond D, Wozney JM, Boedtker H 1977 RNA molecular weight determinations by gel electrophoresis under denaturing conditions, a critical reexamination. Biochemistry 16:4743-4751

21. Robillard JE, Gomez RA, VanOrden D, Smith FG, Jr. 1982 Comparison of the adrenal and renal responses to angiotensin II in fetal lambs and adult sheep. Circ Res 50:140-147

22. Haber E, Koerner T, Page LB, Kliman B, Purnobe A 1969 Application of a radioimmunoassay for angiotensin $\mathrm{I}$ to the physiologic measurements of plasma renin activity in normal human subjects. J Clin Endocrinol Metab 29:1349-1355

23. Zar JH 1984 Biostatistical Analysis. Prentice Hall, Engelwood Cliffs, NJ

24. Robillard JE, Nakamura KT 1988 Neurohormonal regulation of renal function during development. Am J Physiol 244:R249-R256

25. Shanmugam S, Monnot C, Corvol P, Gasc J 1994 Distribution of Type 1 angiotensin II receptor subtype messenger RNAs in the rat fetus. Hypertension 23:137-141
26. Ray PE, Aguilera G, Kopp JB, Horikoshi S, Klotman PE 1991 Angiotensin II receptor-mediated proliferation of cultured human fetal mesangial cells. Kidney Int 40:764-771

27. Dzau VJ, Brody T, Ellison KE, Pratt RE, Ingelfinger JR 1987 Tissue-specific regulation of renin expression in the mouse. Hypertension 9:III36-III41

28. Winter JSD 1992 Fetal and neonatal adrenocortical physiology. In: Polin RA Fox WW (eds) Fetal and Neonatal Physiology, WB Saunders, Philadelphia, pp 18291841

29. Gomez RA, Robillard JE 1984 Developmental aspects of the renal response to hemorrhage during converting-enzyme inhibition in fetal lambs. Circ Res 54:301-312

30. Segar JL, Mazursky JE, Robillard JE 1994 Changes in ovine renal sympathetic nerve activity and baroreflex function at birth. Am J Physiol 267:H1824-H1832

31. Douglas JG 1987 Corticosteroids decrease glomerular angiotensin receptors. Am J Physiol 252:F453-F457

32. Chappell MC, Jacobson DW, Tallant EA 1992 Glucocorticoids down-regulate both $\mathrm{AT}_{1}$ and $\mathrm{AT}_{2}$ angiotensin II receptors in pancreatic acinar cells. Hypertension 20:435(abstr)

33. Aguilear G, Kapur S, Feuillan P, Sunar-Akbasak B, Bathia AJ 1994 Developmental changes in angiotensin II receptor subtypes and $\mathrm{AT}_{1}$ receptor mRNA in rat kidney. Kidney Int 46:973-979

34. Phillips MI, Speakman EA, Kimura B 1993 Tissue Renin-Angiotensin Systems. In: Raizada MK, Phillips MI, Sumners C (eds) Cellular and Molecular Biology of the Renin-Angiotensin System, CRC Press, Boca Raton, LA, pp 97-130

35. Kalimi M, Gupta S 1982 Physiochemical characterization of rat liver glucocorticoid receptor during development. J Biol Chem 257:13324-13328

36. Feldman D 1974 Ontogeny of rat hepatic glucocorticoid receptors. Endocrinology 95:1219-1227

37. Sumners C, Fregly MJ 1989 Modulation of angiotensin II binding sites in neuronal cultures by mineralocorticoids. Am J Physiol 256:C121-C129

38. Gomez RA, Cassis L, Lynch KR, Chevalier RL, Wilfong N, Carey RM, Peach MJ 1988 Fetal expression of the angiotensinogen gene. Endocrinology 123:2298

39. Baker KM, Singer HA 1988 Identification and characterization of guinea pig angiotensin II ventricular and atrial receptors: coupling to inositol phosphate production. Circ Res 62:896-904

40. Sechi LA, Grady EF, Griffin CA, Kalinyak JE, Schambelan M 1991 Characterization of angiotensin II receptor subtypes in the rat kidney and heart using the non-peptide antagonists DuP753 and PD 123177. J Hypertens 9:S224-S225

41. Reiss K, Capasso JM, Huang H, Meggs LG, Li P, Anversa P 1993 ANG II receptors, c-myc, and c-jun in myocytes after myocardial infarction and ventricular failure. Am J Physiol 264:H760-H769

42. Chernin MI, Candia AF, Stark LL, Aceto JF, Baker KM 1990 Fetal expression of renin, angiotensin, and atriopeptin genes in chick heart. Clin Exp Hypertens 12:617629

43. Iwai $\mathrm{N}$, Inagami $\mathrm{T} 1992$ Regulation of the expression of the rat angiotensin II receptor mRNA. Biochem Biophys Res Commun 182:1094-1099

44. Kohara K, Brosnihan KB, Ferrario CM, Milsted A 1992 Peripheral and central angiotensin II regulates expression of genes of the renin-angiotensin system. Am J Physiol 262:E651-E657 